\title{
MEMBANGUN MODEL PENYEBARAN PERILAKU MEROKOK BERDASARKAN FAKTOR BIOLOGIS DAN FAKTOR LINGKUNGAN SOSIAL
}

\author{
Govan'1, R. Ratianigsih², J. W. Puspita ${ }^{3}$ \\ 1,2,3Program Studi Matematika Jurusan Matematika FMIPA Universitas Tadulako \\ Jalan Soekarno-Hatta Km. 09 Tondo, Palu 94118, Indonesia. \\ 1Ghovandgnr@rocketmail.com, 2Ratianigsih@yahoo.com, 3Juni.wpuspita@yahoo.com.
}

\begin{abstract}
Cigarette is a most dangerous killer in the world. Substances that contained in the cigarette causes many diseases. For example heart attack, cancer, and other health and social problems. This research discusses the behavior spreading of smoking based on biological and social environment factor. The model divided the population into 5 subpopulations, namely potential smoker $(S)$, given treatment $\left(\mathrm{S}_{\mathrm{T}}\right)$, beginner smoker $(\mathrm{D})$, smoker subpopulation (A) and recovery subpopulation. The stability of the governed differential equation system, that have 2 critical points namely free cigarette and endemic critical point, that examined at the critical points using linearitation method, and Routh-Hurwitz criterion gives basic reproduction ratio that describe the threshold of spread of smoking behavior. The stability analysis also shows the smoking behavior will be vanish if $R_{0}<1$, and endemic if $R_{0}>1$. For parameter values given, the simulation shows the smoker will never vanish related to $\mathrm{R}_{0}=305,3185523$. It means that the smoker will endemic in population.
\end{abstract}

Key words $\quad$ : Mathematical Model, Linearity Method, Rout-Hurwitz Criterion, System stability, Basic Reproduction Ratio.

\begin{abstract}
Abstrak
Rokok merupakan pembunuh paling berbahaya di dunia. Bahan-bahan berbahaya terkandung dalam rokok dapat memicu timbulnya berbagai penyakit seperti serangan jantung, kanker dan banyak lagi masalah kesehatan dan sosial lainnya. Penelitian ini mengkaji penyebaran perilaku merokok berdasarkan faktor biologis dan faktor lingkungan sosial. Model ini membagi populasi menjadi lima subpopulasi yaitu subpopulasi perokok potensial (S), subpopulasi yang diberikan treatment $\left(\mathrm{S}_{\mathrm{T}}\right)$, subpopulasi yang hanya coba-coba merokok (D), subpopulasi perokok (A), dan yang telah berhenti merokok (R). Kestabilan Dari Sistem Persamaan Diferensial yang dikontruksi, didapatkan dua titik kritis yaitu titik kritis bebas rokok dan titik kritis endemik. Kestabilan sistem dianalisa di titik kritisnya dengan metode linearisasi dan Kriteria Rout-Hurwitz. Analisa tersebut memunculkan Bilangan Reproduksi Dasar yang merupakan ambang batas terjadinya penyebaran perilaku merokok. Analisa kestabilan juga memperlihatkan bahwa perilaku merokok akan hilang jika $\mathrm{R}_{0}<1$, dan akan endemik jika $\mathrm{R}_{0}>1$. Untuk nilai-nilai parameter yang diberikan, simulasi menunjukan bahwa perilaku merokok tidak akan pernah hilang dalam populasi. Hal ini ditunjukan pula melalui nilai $\mathrm{R}_{0}=305,3185523$ yang berarti bahwa perilaku merokok bersifat endemik.
\end{abstract}

Kata Kunci : Model Matematika, Metode Linearisasi, Kriteria Rout-Hurwitz, Kestabilan sistem, Bilangan Reproduksi Dasar. 


\section{PENDAHULUAN}

\subsection{Latar Belakang}

Rokok merupakan salah satu pembunuh paling berbahaya di dunia. Bukti-bukti dari penelitian 10 tahun terakhir menunjukan bahwa lebih dari 50\% perokok meninggal karena kecanduan. Menjelang tahun 2030 terdapat 8 juta orang di dunia akan meninggal setiap tahun kerena rokok ${ }^{[6]}$. Bahkan, selama abad 21 ini, diperkirakan 1 milyar jiwa orang akan melayang kerena rokok [10]. Rokok juga dapat menstimulasi kanker dan berbagai penyakit yang lain seperti penyempitan pembuluh darah, tekanan darah tinggi, jantung, paru-paru, dan bronchitis kronis [3]. Bagi ibu hamil, rokok dapat menyebabkan kelahiran prematur, berat badan bayi rendah, mortalitas prenatal, kemungkinan lahir dalam keadaan cacat, dan mengalami gangguan dalam perkembangan [1]. Hal ini dikarenakan rokok mengandung kurang lebih 4000 senyawa kimia, dan setidaknya 200 diantaranya beracun dan dinyatakan berbahaya bagi kesehatan, sementara 43 bahan kimia lainnya dapat memicu kanker [8].

Anak-anak di Indonesia sudah ada yang mulai merokok pada usia 9 tahun [7]. Usia pertama kali merokok pada umumya berkisar antara 11-13 tahun dan mereka pada umumnya merokok sebelum usia 18 tahun ${ }^{[9]}$. Data WHO juga semakin mempertegas bahwa seluruh jumlah perokok yang ada di dunia sebanyak $30 \%$ adalah kaum remaja ${ }^{[7]}$.

Ada banyak alasan atau faktor-faktor yang melatarbelakangi perilaku merokok, diantaranya adalah faktor biologis dan faktor lingkungan sosial. Secara biologis, nikotin yang terkandung dalam rokok tersebut akan menekan kemampuan otak untuk mengalami kenikmatan, sehingga perokok akan selalu membutuhkan kadar nikotin yang semakin tinggi untuk mencapai tingkat kepuasan dan ketergantungan seseorang pada rokok secara biologis [5]. Secara umum menurut Kurt Lewin, perilaku merokok merupakan fungsi dari lingkungan dan individu. Artinya, perilaku merokok selain disebabkan faktor-faktor dari dalam diri, juga disebabkan faktor lingkungan sosial ${ }^{[4]}$.

Salah satu upaya pemerintah dalam bidang pengabdian pada masyarakat untuk mengurangi prevalensi merokok adalah melalui promosi kesehatan. Promosi kesehatan ini berupa penyuluhan tentang bahaya merokok sebagai upaya preventif untuk menggurangi kebiasaan merokok. Pada dunia kesehatan, sasaran penyuluhan kesehatan adalah masyarakat umum, orientasi masyarakat pedesaan, masyarakat kelompok khusus, dan individu. 
Penelitian ini akan mengkaji penyebaran perilaku merokok berdasarkan faktor biologis dan faktor lingkungan sosial yang direpresentasikan dalam sebuah model matematika. Model penyebaran ini dikontruksi berdasarkan konsep model Susceptible Infected Recovered (SIR). Model SIR digunakan untuk mengetahui penyebaran perilaku merokok dalam suatu populasi. Dari model tersebut akan terbentuk suatu sistem persamaan diferensial. Dari sistem tersebut, dapat dicari titik kritisnya yang selanjutnya dianalisis kestabilannya [2]. Dari titik kritis yang diperoleh, dapat pula dicari bilangan reproduksi dasar, dimana bilangan reproduksi dasar merupakan ambang batas terjadinya penyebaran perilaku merokok.

\subsection{Rumusan Masalah}

Berdasarkan latar belakang di atas, dapat dirumuskan beberapa permasalahan yang dikemukakan dalam penelitian ini adalah:

1. Bagaimana model matematika penyebaran perilaku merokok berdasarkan faktor biologis dan lingkungan sosial?

2. Bagaimana analisis kestabilan dari model yang telah diberikan?

\subsection{Tujuan Penelitian}

Berdasarkan rumusan masalah diatas, maka tujuan dari peneliatian ini adalah:

1. Mendapatkan model matematika dari penyebaran perilaku merokok berdasarkan faktor biologis dan lingkungan sosial.

2. Mendapatkan analisis kestabilan model di titik-titik kritis.

\subsection{Manfaat Penelitian}

Manfaat dari penelitian ini adalah mengetahui secara matematis mengenai penyebaran perilaku merokok berdasarkan faktor biologis dan faktor lingkungan sosial.

\subsection{Asumsi Penelitian}

Asumsi yang digunakan dalam penelitian ini adalah sebagai berikut:

1. Setiap individu yang lahir dalam populasi diasumsikan rentan menjadi perokok.

Penularan perilaku merokok terjadi karena adanya interaksi antara subpopulasi rentan dengan subpopulasi perokok.

2. Jumlah rokok yang dikonsumsi setiap hari tidak dipertimbangkan.

3. Perlakuan (treatment) misalnya berupa penyuluhan hanya diberikan pada subpopulasi perokok potensial. 


\section{METODE PENELITIAN}

Penelitian ini bersifat kajian kualitatif terhadap SPD non linear dengan menggunakan metode linearisasi. SPD yang dikaji dibangun atas variabel-variabel $S, S_{T}, D, A, R$, adapun langkah kajian pada setiap kombinasi adalah:

a. Mencari titik kritis dari SPD yang telah direvisi dengan meninjau persamaan pembangun pada kondisi stagnan, selanjutnya dievaluasi menggunakan matriks Jacobian.

b. Mencari bilangan reproduksi dasar dengan Next Generation Matrix

c. Menganalisis kestabilan sistem dengan cara melihat tanda akar-akar polinomial karakteristik dari matriks Jacobian yang telah dievaluasi pada titik kritis. Karena polinomial karakteristik dari matriks Jacobian yang diperoleh berderajat tinggi, maka digunakan bantuan kriteria RouthHurwitz untuk mempermudahnya.

d. Melakukan simulasi dengan memasukkan nilai-nilai parameter yang telah ditentukan ke dalam SPD.

III. HASIL DAN PEMBAHASAN

\subsection{Model Matematika Penyebaran Perilaku Merokok}

Kontruksi model yang menggambarkan penyebaran infeksi tersebut berdasarkan faktor biologis dan faktor lingkungan sosial digambarkan sebagai berikut:

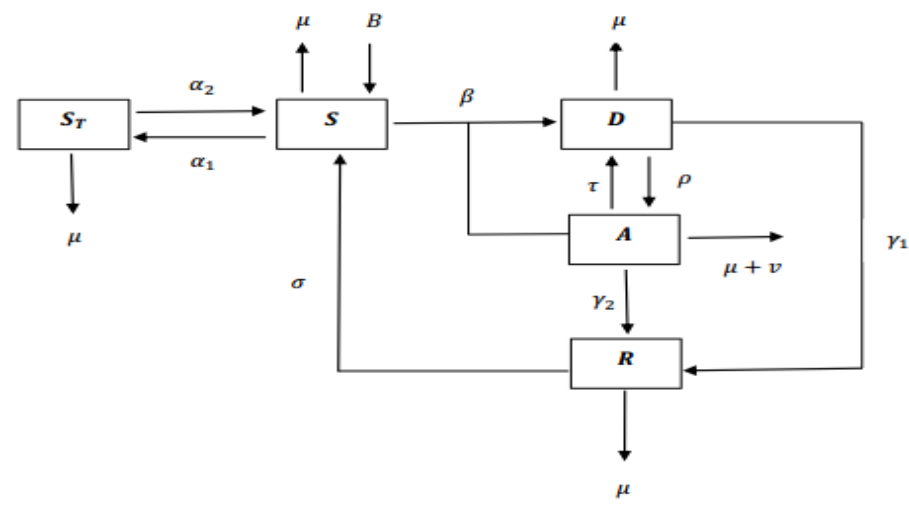

Gambar 1. Kompartemen Penyebaran Perilaku Merokok

Melalui diagram alir pada Gambar 1, populasi manusia dibagi menjadi 5 subpopulasi yaitu: subpopulasi yang berpotensi menjadi perokok $S(t)$, subpopulasi yang diberikan treatment $S_{T}(t)$, subpopulasi yang hanya coba-coba merokok rokok $D(t)$, subpopulasi perokok $A(t)$, subpopulasi yang sembuh dari pengaruh rokok $R(t)$, dibangun dalam suatu model matematika dalam bentuk sistem Persamaan diferensial tak linier sebagai berikut::

$\frac{d S}{d t}=\mathrm{B}-\left(\beta A+\mu+\alpha_{1}\right) S+\sigma R+\alpha_{2} S_{T}$

$\frac{d S_{T}}{d t}=\alpha_{1} S-\left(\alpha_{2}+\mu\right) S_{T}$ 


$$
\begin{aligned}
& \frac{d D}{d t}=\beta S A+\tau A-\left(\rho+\gamma_{1}+\mu\right) D \\
& \frac{d A}{d t}=\rho D-\left(\mu+v+\gamma_{2}+\tau\right) A \ldots \\
& \frac{d R}{d t}=\gamma_{1} D+\gamma_{2} A-(\sigma+\mu) R \ldots \ldots
\end{aligned}
$$

\subsection{Menentukan Titik Kritis}

Titik kritis diperoleh dengan memandang persamaan (1)-(5) dalam keadaan stagnan atau tidak terdapat perubahan dalam populasi sebagai berikut:

$\frac{d S_{T}}{d t}=0, \frac{d S}{d t}=0, \frac{d D}{d t}=0, \frac{d A}{d t}=0, \frac{d R}{d t}=0$

Sehingga diperoleh dua titik kritis. Titik kritis pertama yang menyatakan populasi bebas rokok yang diekspresikan sebagai $T_{1}=\left(\frac{\alpha_{1} B}{\mu\left(\mu+\alpha_{1}+\alpha_{2}\right)}, \frac{B\left(\alpha_{2}+\mu\right)}{\mu\left(\mu+\alpha_{1}+\alpha_{2}\right)}, 0,0,0\right)$. Eksistensi titik kritis bebas rokok $\mathrm{T}_{1}$ tercapai saat $S_{T}>0$ dan $S>0$. Titik kritis kedua yang menyatakan keendemikan perilaku merokok dalam populasi. Titik kritis ini diekspresikan sebagai $T_{2}=$ $\left(S_{T}{ }^{*}, S^{*}, D^{*}, A^{*}, R^{*}\right)$, dimana:

$$
\begin{aligned}
& S_{T}^{*}=\frac{\alpha_{1}\left(\rho \mu+\rho v+\rho \gamma_{2}+\gamma_{1} \mu+\gamma_{1} v+\gamma_{1} \tau+\gamma_{1} \gamma_{2}+\mu^{2}+\mu v+\mu \gamma_{2}+\mu \tau\right)}{\beta \rho\left(\alpha_{2}+\mu\right)} \\
& S^{*}=\frac{\left(\rho \mu+\rho v+\rho \gamma_{2}+\gamma_{1} \mu+\gamma_{1} v+\gamma_{1} \tau+\gamma_{1} \gamma_{2}+\mu^{2}+\mu v+\mu \gamma_{2}+\mu \tau\right)}{\beta \rho} \\
& D^{*}=\frac{\left(\mu+v+\gamma_{2}+\tau\right)\left(B \beta \rho\left(\alpha_{2}+\mu\right)-\mu\left(\alpha_{2}+\mu+\alpha_{1}\right)\left(\rho \mu+\rho v+\rho \gamma_{2}+\gamma_{1} \mu+\gamma_{1} v+\gamma_{1} \tau+\gamma_{1} \gamma_{2}+\mu^{2}+\mu v+\mu \gamma_{2}+\mu \tau\right)\right)(\sigma+\mu)}{\beta \rho\left(\left(\sigma\left(\rho \mu+\rho v+\mu^{2}+\mu v+\mu \gamma_{2}+\mu \tau\right)+\mu\left(\rho \mu+\rho v+\rho \gamma_{2}+\gamma_{1} \mu+\gamma_{1} v+\gamma_{1} \tau+\gamma_{1} \gamma_{2}+\mu^{2}+\mu v+\mu \gamma_{2}+\mu \tau\right)\right)\right)} \\
& A^{*}=\frac{\left(B \beta \rho\left(\alpha_{2}+\mu\right)-\mu\left(\alpha_{2}+\mu+\alpha_{1}\right)\left(\rho \mu+\rho v+\rho \gamma_{2}+\gamma_{1} \mu+\gamma_{1} v+\gamma_{1} \tau+\gamma_{1} \gamma_{2}+\mu^{2}+\mu v+\mu \gamma_{2}+\mu \tau\right)\right)(\sigma+\mu)}{\beta\left(\sigma\left(\rho \mu+\rho v+\mu^{2}+\mu v+\mu \gamma_{2}+\mu \tau\right)+\mu\left(\rho \mu+\rho v+\rho \gamma_{2}+\gamma_{1} \mu+\gamma_{1} v+\gamma_{1} \tau+\gamma_{1} \gamma_{2}+\mu^{2}+\mu v+\mu \gamma_{2}+\mu \tau\right)\right)} \\
& R^{*}=\frac{\left(\rho \gamma_{2}+\gamma_{1}\left(\mu+v+\gamma_{2}+\tau\right)\right)\left(B \beta \rho\left(\alpha_{2}+\mu\right)-\mu\left(\alpha_{2}+\mu+\alpha_{1}\right)\left(\rho \mu+\rho v+\rho \gamma_{2}+\gamma_{1} \mu+\gamma_{1} v+\gamma_{1} \tau+\gamma_{1} \gamma_{2}+\mu^{2}+\mu v+\mu \gamma_{2}+\mu \tau\right)\right)}{\beta \rho\left(\left(\sigma\left(\rho \mu+\rho v+\mu^{2}+\mu v+\mu \gamma_{2}+\mu \tau\right)+\mu\left(\rho \mu+\rho v+\rho \gamma_{2}+\gamma_{1} \mu+\gamma_{1} v+\gamma_{1} \tau+\gamma_{1} \gamma_{2}+\mu^{2}+\mu v+\mu \gamma_{2}+\mu \tau\right)\right)\right)}
\end{aligned}
$$

Eksistensi titik kritis $T_{2}$ yang menggambarkan keendemikan perilaku merokok dijamin oleh kondisi berikut:

$$
\frac{B \beta \rho\left(\alpha_{2}+\mu\right)}{\mu\left(\alpha_{2}+\mu+\alpha_{1}\right)\left(\rho \mu+\rho v+\rho \gamma_{2}+\gamma_{1} \mu+\gamma_{1} v+\gamma_{1} \tau+\gamma_{1} \gamma_{2}+\mu^{2}+\mu v+\mu \gamma_{2}+\mu \tau\right)}>1
$$

\subsection{Menentukan Bilangan Reproduksi Dasar}

Bilangan reproduksi dasar didapatkan dengan membangun matriks yang menunjukkan rata-rata jumlah individu terinfeksi baru dengan metode Next Generation Matrix (NGM). Misalkan $\boldsymbol{x}=(D, A)^{T}$, sehingga persamaan (1) - (5) dapat ditulis sebagai:

$\frac{d x}{d t}=F(x)-V(x)$ 
Dengan $F(x)$ adalah matriks transmisi yaitu matriks yang berisi laju infeksi individu baru karena kontak, dan $V(\boldsymbol{x})$ adalah matriks transisi yaitu matriks yang berisi laju transfer masuk dan keluar subpopulasi terinfeksi. Sehingga didapatkan:

$F(\boldsymbol{x})=\left[\begin{array}{c}\beta S A \\ 0\end{array}\right]$

$V(\boldsymbol{x})=\left[\left(\begin{array}{c}\left(\rho+\gamma_{1}+\mu\right) D \\ \left(\mu+v+\gamma_{2}+\tau\right) A\end{array}\right)-\left(\begin{array}{c}\tau A \\ \rho D\end{array}\right)\right]$

Kemudian dibangun matriks $\mathrm{T}(\boldsymbol{x})$ dan $\mathrm{E}(\boldsymbol{x})$ yaitu matriks Jacobian dari $F(\boldsymbol{x})$ dan $V(\boldsymbol{x})$ yang dievaluasi di titik kritis bebas rokok.

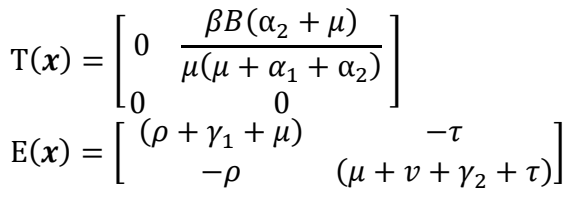

NGM didapatkan dari perkalian $\mathrm{T}(\boldsymbol{x})$ dengan invers $\mathrm{E}(\boldsymbol{x})$ sebagai berikut :

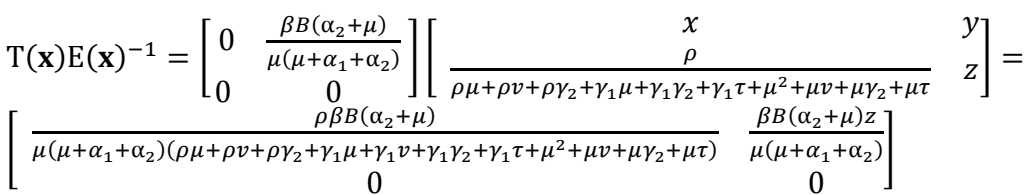

Dimana:

$x=\frac{\mu+v+\gamma_{2}+\tau}{\rho \mu+\rho v+\rho \gamma_{2}+\gamma_{1} \mu+\gamma_{1} \gamma_{2}+\gamma_{1} \tau+\mu^{2}+\mu v+\mu \gamma_{2}+\mu \tau}$
$y=\frac{\tau}{\rho \mu+\rho v+\rho \gamma_{2}+\gamma_{1} \mu+\gamma_{1} \gamma_{2}+\gamma_{1} \tau+\mu^{2}+\mu v+\mu \gamma_{2}+\mu \tau}$
$Z=\frac{\rho+\gamma_{1}+\mu}{\rho \mu+\rho v+\rho \gamma_{2}+\gamma_{1} \mu+\gamma_{1} \gamma_{2}+\gamma_{1} \tau+\mu^{2}+\mu v+\mu \gamma_{2}+\mu \tau}$

Sehingga didapatkan nilai $R_{0}$ :

$R_{0}=\rho\left(T(\boldsymbol{x}) \mathrm{E}(\boldsymbol{x})^{-1}\right)$

$R_{0}=\frac{\rho \beta B\left(\alpha_{2}+\mu\right)}{\mu\left(\mu+\alpha_{1}+\alpha_{2}\right)\left(\rho \mu+\rho v+\rho \gamma_{2}+\gamma_{1} \mu+\gamma_{1} v+\gamma_{1} \gamma_{2}+\gamma_{1} \tau+\mu^{2}+\mu v+\mu \gamma_{2}+\mu \tau\right)}$

Nilai $R_{0}$ pada persamaan (15) memperlihatkan bahwa tingkat pertambahan infeksi baru dalam populasi rentan dipengaruhi oleh laju infeksi terhadap tingkat perekrutan individu selama masa periode infeksi. 


\subsection{Analisis Kestabilan}

Untuk analisi kestabilan titik kritis bebas rokok terlebih dahulu dilakukan transformasi karena $S$ dan $S_{T}$ tidak sama dengan nol. Matriks Jacobi persamaan (1) - (5) yang dievaluasi dititik $(0,0,0,0,0)$ memberikan persamaan karakterisitik dalam $\lambda$ sebagai berikut:

$(\sigma+\mu+\lambda)\left(a_{0} \lambda^{4}+a_{1} \lambda^{3}+a_{2} \lambda^{2}+a_{3} \lambda+a_{4}\right)=0$

dengan :

$a_{0}=\left(\alpha_{1} \mu+\mu^{2}+\alpha_{2} \mu\right)$

$a_{1}=\left(\mu^{2} \tau+2 \mu^{3}+\mu \gamma_{2} \alpha_{2}+\gamma_{1} \mu \alpha_{1}+\mu v \alpha_{2}+\rho \mu \alpha_{1}+\gamma_{1} \mu \alpha_{1}+\mu \tau \alpha_{2}+\mu v \alpha_{1}+\mu^{2} \rho+\mu^{2} \gamma_{1}+2 \mu^{2}+\right.$ $\left.\mu \tau \alpha_{1}+\mu^{2} v+\mu^{2} \gamma_{2}+2 \mu^{2} \alpha_{1}+\left(\alpha_{1} \mu+\mu^{2}+\alpha_{2} \mu\right)\left(\alpha_{1}+2 \mu+\alpha_{2}\right)\right)$

$a_{2}=\left(\mu\left(\mu+\alpha_{1}+\alpha_{2}\right)\left(\rho \mu+\rho v+\rho \gamma_{2}+\gamma_{1} v+\gamma_{1} \mu+\gamma_{1} \gamma_{2}+\gamma_{1} \tau+\mu^{2}+\mu v+\mu \gamma_{2}+\mu \tau\right)\left(1-R_{0}\right)+\right.$ $\left(\mu^{2} \tau+2 \mu^{3}+\mu \gamma_{2} \alpha_{2}+\gamma_{1} \mu \alpha_{1}+\mu v \alpha_{2}+\rho \mu \alpha_{1}+\gamma_{1} \mu \alpha_{1}+\mu \tau \alpha_{2}+\mu v \alpha_{1}+\mu^{2} \rho+\mu^{2} \gamma_{1}+2 \mu^{2}+\right.$ $\left.\left.\mu \tau \alpha_{1}+\mu^{2} v+\mu^{2} \gamma_{2}+2 \mu^{2} \alpha_{1}\right)\right)$

$a_{3}=\left(\mu\left(\mu+\alpha_{1}+\alpha_{2}\right)\left(\rho \mu+\rho v+\rho \gamma_{2}+\gamma_{1} \mu+\gamma_{1} \gamma_{2}+\gamma_{1} \tau+\mu^{2}+\mu v+\mu \gamma_{2}+\mu \tau\right)(1-\right.$ $R_{0}\left(\alpha_{1}+2 \mu+\alpha_{2}\right)+\left(\mu^{2} \tau+2 \mu^{3}+\mu \gamma_{2} \alpha_{2}+\gamma_{1} \mu \alpha_{1}+\mu v \alpha_{2}+\rho \mu \alpha_{1}+\gamma_{1} \mu \alpha_{1}+\mu \tau \alpha_{2}+\mu v \alpha_{1}+\right.$ $\left.\mu^{2} \rho+\mu^{2} \gamma_{1}+2 \mu^{2}+\mu \tau \alpha_{1}+\mu^{2} v+\mu^{2} \gamma_{2}+2 \mu^{2} \alpha_{1}\right)\left(\alpha_{1} \mu+\mu^{2}+\alpha_{2} \mu\right)$

$a_{4}=\left(\mu\left(\mu+\alpha_{1}+\alpha_{2}\right)\left(\rho \mu+\rho v+\rho \gamma_{2}+\gamma_{1} v+\gamma_{1} \mu+\gamma_{1} \gamma_{2}+\gamma_{1} \tau+\mu^{2}+\mu v+\mu \gamma_{2}+\mu \tau\right)(1-\right.$ $R_{0}\left(\alpha_{1} \mu+\mu^{2}+\alpha_{2} \mu\right)$

Persamaan karakteristik tersebut memberikan sebuah nilai eigen $\lambda=-(\sigma+\mu)$ yang bernilai negatif. Sedangkan untuk empat nilai eigen lainnya digunakan metode Routh-Hurwitz untuk menganalisa kestabilan sistem. Perhatikan bahwa koefisien $a_{0}$ dan $a_{1}$ bernilai positif, sedangkan koefisien $a_{2}, a_{3}$ dan $a_{4}$ bernilai positif jika $R_{0}<1, R_{0}\left(\alpha_{1}+2 \mu+\alpha_{2}\right)<1$ dan $R_{0}\left(\alpha_{1} \mu+\mu^{2}+\alpha_{2} \mu\right)<1$. Koefisien-koefisien tersebut ditabelkan mengikuti kriteria RouthHurwitz sebagai berikut:

$\begin{array}{cccc}\lambda^{4} & a_{0} & a_{2} & a_{4} \\ \lambda^{3} & a_{1} & a_{3} & 0 \\ \lambda^{2} & b_{1} & b_{2} & \\ \lambda^{1} & b_{3} & 0 & \\ \lambda^{0} & b_{4} & & \end{array}$

dengan :

$b_{1}=\frac{a_{1} \cdot a_{2}-a_{0} \cdot a_{3}}{a_{1}}, b_{3}=\frac{b_{1} \cdot a_{3}-b_{2} \cdot a_{1}}{b_{1}}, b_{2}=b_{4}=a_{4}$

Berdasarkan kriteria kestabilan Routh-Hurwitz, titik kritis $\mathrm{T}_{1}$ akan stabil asimtotis lokal jika semua koefisien persamaan karakteristik bernilai positif dan semua elemen-elemen dari kolom 
pertama pada tabel Routh-Hurwitz mempunyai tanda yang sama yaitu, $b_{1}>0, b_{3}>0, R_{0}<1$, $R_{0}\left(\alpha_{1}+2 \mu+\alpha_{2}\right)<1$ dan $R_{0}\left(\alpha_{1} \mu+\mu^{2}+\alpha_{2} \mu\right)<1$.

Analisis Kestabilan titik kritis endemik juga terlebih dahulu dilakukan transformasi. Sehingga linearisasi sistem dititik kritis baru $(0,0,0,0,0)$ memberikan persamaan karakterisitik dalam $\lambda$ sebagai berikut:

$a_{0} \lambda^{5}+a_{1} \lambda^{4}+a_{2} \lambda^{3}+a_{3} \lambda^{2}+a_{4} \lambda^{1}+a_{5} \lambda^{0}=0$

Dengan :

$$
\begin{aligned}
& a_{1}=\left(\sigma+v+\beta x\left(R_{0}-1\right)+\alpha_{1}+\gamma_{1}+\rho+5 \mu+\alpha_{2}+\tau+\gamma_{1}\right) \\
& a_{2}=\left(\left(10 \mu^{2}+4 \gamma_{1}+4 \alpha_{2}+4 \beta x\left(R_{0}-1\right)+4 \sigma+4 v+4 \alpha_{1}+4 \tau\right) \mu+\left(\gamma_{2}+v+\beta x\left(R_{0}-1\right)+\alpha_{1}+\right.\right. \\
& \left.\gamma_{1}+\rho+\alpha_{2}+\tau\right) \sigma+\beta x\left(R_{0}-1\right)\left(\gamma_{2}+v+\tau+\alpha_{1}+\rho+\alpha_{2}+\gamma_{1}\right)+\left(\gamma_{1}+v+\rho+\tau+\gamma_{2}\right) \alpha_{2}+ \\
& \left.\left(\gamma_{2}+v+\alpha_{2}\right) \rho+\left(\gamma_{2}+v+\tau+\alpha_{1}\right) \gamma_{1}+\alpha_{1}\left(\tau+\gamma_{2}+v\right)\right) \\
& a_{3}=\left(10 \mu^{3}+\left(6 \gamma_{1}+6 v+6 \beta x\left(R_{0}-1\right)-6 \sigma+6 \rho+6 \alpha_{1}+6 \gamma_{2}+6 \tau+6 \alpha_{2}\right) \mu^{2}+\right. \\
& \left(\left(3 \rho+3 \tau+3 \gamma_{1}+3 \gamma_{2}+3 v+3 \alpha_{2}+3 \alpha_{1}+4 \beta x\left(R_{0}-1\right)\right) \sigma+3 \beta x\left(R_{0}-1\right)\left(\gamma_{2}+\tau+v+\alpha_{2}+\rho+\right.\right. \\
& \left.\gamma_{1}\right)+\left(3 v+3 \gamma_{2}+3 \tau+3 \rho+3 \gamma_{1}\right) \alpha_{2}+\left(3 \gamma_{2}+3 v+3 \alpha_{1}\right) \rho+\left(3 v+3 \tau+3 \gamma_{2}+3 \alpha_{1}\right) \gamma_{1}+ \\
& \left.3 \alpha_{1}\left(\tau+\gamma_{2}+v\right)\right) \mu+\left(2 x \beta\left(R_{0}-1\right)\left(\frac{1}{2} \alpha_{2}+\frac{1}{2} \rho+\frac{1}{2} \gamma_{1}+v+\gamma_{2}+\tau\right)+\left(\gamma_{1}+v+\rho+\tau+\gamma_{2}\right) \alpha_{2}+\right. \\
& \left.\left(\gamma_{2}+v+\alpha_{1}\right) \rho+\left(\gamma_{2}+v+\tau+\alpha_{1}\right) \gamma_{1}+\alpha_{1}\left(\tau+\gamma_{2}+v\right)\right) \sigma+x \beta\left(R_{0}-1\right)\left(\left(v+\gamma_{2}+\tau+\rho+\right.\right. \\
& \left.\left.\left.\gamma_{1}\right) \alpha_{2}+\left(v+\gamma_{2}\right) \rho+\gamma_{1}\left(\tau+\gamma_{2}+v\right)\right)+\left(\alpha_{1}+\alpha_{2}\right)\left(\left(v+\gamma_{2}\right) \rho+\gamma_{1}\left(\tau+\gamma_{2}+v\right)\right)\right) \\
& a_{4}=\left(\left(5 \mu^{4}+\left(\gamma_{1}+\alpha_{2}+\rho+x \beta\left(R_{0}-1\right)+v+\alpha_{1}+\tau+\gamma_{2}\right) 4 \mu^{3}\right.\right. \\
& +\left(\left(3 \rho+3 \tau+3 \gamma_{1}+3 \alpha_{2}+3 \alpha_{1}+5 x \beta\left(R_{0}-1\right)\right) \sigma\right. \\
& +3 x \beta\left(R_{0}-1\right)\left(v+\gamma_{2}+\tau+\rho+\gamma_{1}+\alpha_{2}\right)+\left(v+\gamma_{2}+\tau+\rho+\gamma_{1}\right) 3 \alpha_{2} \\
& \left.+\left(v+\gamma_{2}+\alpha_{1}\right) 3 \rho+\left(v+\gamma_{2}+\alpha_{1}+\tau\right) 3 \gamma_{1}-3 \alpha_{1}\left(v+\gamma_{2}+\tau\right)\right) \mu^{2} \\
& +\left(x \beta\left(R_{0}-1\right)\left(5 v+5 \gamma_{2}+5 \tau+2 \rho+2 \gamma_{1}+3 \alpha_{2}\right)\right)+\left(v+\gamma_{2}+\tau+\rho+\gamma_{1}\right) 2 \alpha_{2} \\
& \left.+\left(\gamma_{2}+v+\alpha_{1}\right) 2 \rho+\left(\gamma_{2}+v+\tau+\alpha_{1}\right) 2 \gamma_{1}+2 \alpha_{1}\left(\tau+\gamma_{2}+v\right)\right) \sigma \\
& +2 x \beta\left(R_{0}-1\right)\left(\left(v+\gamma_{2}+\tau+\rho+\gamma_{1}\right) \alpha_{2}+\left(v+\gamma_{2}\right) \rho+\gamma_{1}\left(\tau+\gamma_{2}+v\right)\right) \\
& +2\left(\alpha_{1}+\alpha_{2}\right)\left(\left(v+\gamma_{2}\right) \rho+\gamma_{1}\left(\tau+\gamma_{2}+v\right)\right) \\
& +\left(x \beta ( R _ { 0 } - 1 ) \left(\left(2 v+2 \gamma_{2}+2 \tau+\rho+\gamma_{1}\right) \alpha_{2}+\rho v\right.\right. \\
& \left.\left.+\left(\tau+\gamma_{2}+v\right)\left(v+\gamma_{2}+\tau+\gamma_{1}\right)\right)+\left(\alpha_{1}+\alpha_{2}\right)\left(\left(v+\gamma_{2}\right) \rho+\gamma_{1}\left(\tau+\gamma_{2}+v\right)\right)\right) \sigma \\
& \left.+\left(\left(v+\gamma_{2}\right) \rho+\gamma_{1}\left(\tau+\gamma_{2}+v\right)\right) \alpha_{2} x \beta\left(R_{0}-1\right)+\rho y x \beta\left(R_{0}-1\right)\right)
\end{aligned}
$$

$a_{5}=\mu^{5}+\left(\gamma_{2}+v+\tau+\alpha_{2}+\rho+\alpha_{1}+\gamma_{1}+x \beta\left(R_{0}-1\right)\right) \mu^{4}+\left(\left(\gamma_{2}+v+\tau+\alpha_{2}+\rho+\alpha_{1}+\gamma_{1}+\right.\right.$ $\left.2 x \beta\left(R_{0}-1\right)\right) \sigma+x \beta\left(R_{0}-1\right)\left(\gamma_{2}+v+\tau+\alpha_{2}+\rho+\gamma_{1}\right)+\left(v+\gamma_{2}+\tau+\rho+\gamma_{1}\right) \alpha_{2}+\left(v+\gamma_{2}+\right.$ $\left.\left.\alpha_{1}\right) \rho+\gamma_{1}\left(\tau+\gamma_{2}+v+\alpha_{1}\right)+\alpha_{1}\left(\tau+\gamma_{2}+v\right)\right) \mu^{3}+\left(\left(x \beta\left(R_{0}-1\right)\left(\alpha_{2}+\rho+\gamma_{1}+2 v+2 \gamma_{2}+2 \tau\right)+\right.\right.$ 
$\left.\left(\gamma_{1}+v+\rho+\tau+\gamma_{2}\right) \alpha_{2}+\left(\gamma_{2}+v+\alpha_{1}\right) \rho+\left(\gamma_{2}+v+\tau+\alpha_{1}\right) \gamma_{1}+\alpha_{1}\left(\tau+\gamma_{2}+v\right)\right) \sigma+x \beta\left(R_{0}-\right.$ 1) $\left(\left(v+\gamma_{2}+\tau+\rho+\gamma_{1}\right) \alpha_{2}+\left(v+\gamma_{2}\right) \rho+\gamma_{1}\left(\tau+\gamma_{2}+v\right)\right)+\left(\alpha_{1}+\alpha_{2}\right)\left(\left(v+\gamma_{2}\right) \rho+\gamma_{1}\left(\tau+\gamma_{2}+\right.\right.$ $v))) \mu^{2}+\left(\left(\left(x \beta\left(R_{0}-1\right)\left(\left(3 v+3 \gamma_{2}+3 \tau+\rho+\gamma_{1}+\alpha_{2}\right)+\rho v+\left(\tau+\gamma_{2}+v\right)\left(v+\gamma_{2}+\tau+\right.\right.\right.\right.\right.$ $\left.\left.\left.\gamma_{1}\right)\right)+\left(\alpha_{1}+\alpha_{2}\right)\left(\left(v+\gamma_{2}\right) \rho+\gamma_{1}\left(\tau+\gamma_{2}+v\right)\right)\right) \sigma+\left(\left(v+\gamma_{2}\right) \rho+\gamma_{1}\left(\tau+\gamma_{2}+v\right)\right) \mu \alpha_{2} x \beta\left(R_{0}-\right.$ 1))) $R_{0}+\mu y x \beta\left(R_{0}-1\right)$

Dari persamaan karakteristik tersebut didapat koefisien $a_{0}, a_{1}, a_{2}, a_{3}, a_{4}$ dan $a_{5}$ bernilai positif jika $R_{0}>1$. Koefisien-koefisien tersebut ditabelkan mengikuti kriteria Routh-Hurwitz sebagai berikut:

$\begin{array}{cccc}\lambda^{5} & a_{0} & a_{2} & a_{4} \\ \lambda^{4} & a_{1} & a_{3} & a_{5} \\ \lambda^{3} & b_{1} & b_{2} & 0 \\ \lambda^{2} & b_{3} & b_{4}=a_{5} & \\ \lambda^{1} & b_{5} & 0 & \\ \lambda^{0} & a_{5} & & \end{array}$

Dengan:

$b_{1}=\frac{a_{1} a_{2}-a_{0} a_{3}}{a_{1}}, b_{2}=\frac{a_{1} a_{4}-a_{0} a_{5}}{a_{1}}, b_{3}=\frac{b_{1} a_{3}-a_{1} b_{2}}{b_{1}}, b_{5}=\frac{b_{3} b_{2}-b_{1} b_{4}}{b_{3}}$

Berdasarkan kriteria kestabilan Routh-Hurwitz, titik kritis $\mathrm{T}_{2}$ akan stabil asimtotis lokal jika semua koefisien persamaan karakteristik bernilai positif dan semua elemen-elemen dari kolom pertama pada tabel Routh-Hurwitz mempunyai tanda yang sama yaitu, $b_{1}>0, b_{3}>0, b_{5}$ dan $R_{0}>1$.

\subsection{Simulasi}

Untuk melihat dinamika penyebaran perilaku merokok dari model yang dikonstruksi pada persamaan (1) - (5), dilakukan simulasi menggunakan nilai-nilai parameter dan nilai awal sebagai berikut: 


\begin{tabular}{|c|c|c|}
\hline Parameter & Nilai & Sumber \\
\hline $\mathrm{B}$ & 2 & Diasumsikan \\
\hline$\alpha_{1}$ & 0,5 & Diasumsikan \\
\hline$\alpha_{2}$ & 0,1 & Diasumsikan \\
\hline$\beta$ & 0,07 & Vika, dkk (2013) \\
\hline$\gamma_{1}$ & 0.0165 & Erturk, dkk (2012) \\
\hline$\gamma_{2}$ & 0,01 & Vika, dkk (2013) \\
\hline$\rho$ & 0,03 & Zeb, dkk (2013) \\
\hline$\sigma$ & 0,001 & Diasumsikan \\
\hline$\tau$ & 0,01 & Vika, dkk (2013) \\
\hline$\mu$ & 0,0021 & Erturk, dkk (2012) \\
\hline$v$ & 0,01 & Vika, dkk (2013) \\
\hline
\end{tabular}

Tabel 1. Nilai Parameter

Komputasi.

Table 2. Nilai awal untuk tiap subpopuplasi

\begin{tabular}{|c|c|c|}
\hline Subpopulasi & Jumlah (orang) & Sumber \\
\hline$S_{T}(0)$ & 600 & Diasumsikan \\
\hline$S(0)$ & 680 & Diasumsikan \\
\hline$D(0)$ & 50 & Diasumsikan \\
\hline$A(0)$ & 240 & Diasumsikan \\
\hline$R(0)$ & 30 & Diasumsikan \\
\hline
\end{tabular}


Dengan menggunakan program Maple 13 didapatkan grafik dinamika penyebaran perilaku merokok dan grafik level set $R_{0}$ terhadap parameter $\beta$ dan B sebagai berikut:

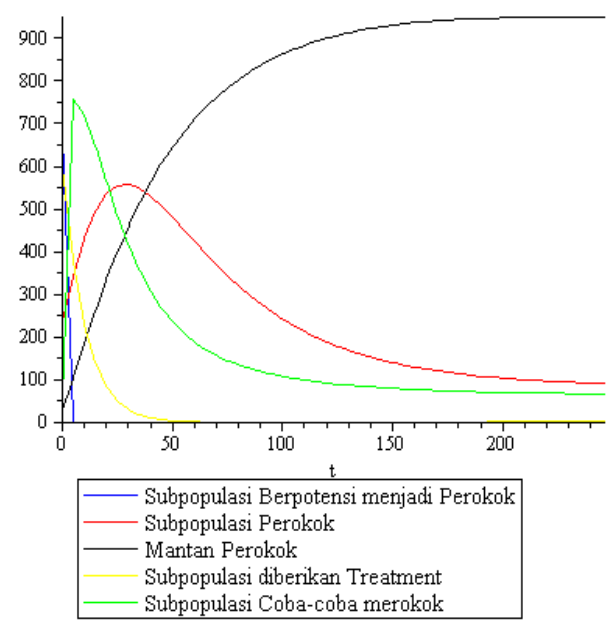

Gambar 2. Dinamika Model

Matematika Penyebaran

Perilaku Merokok

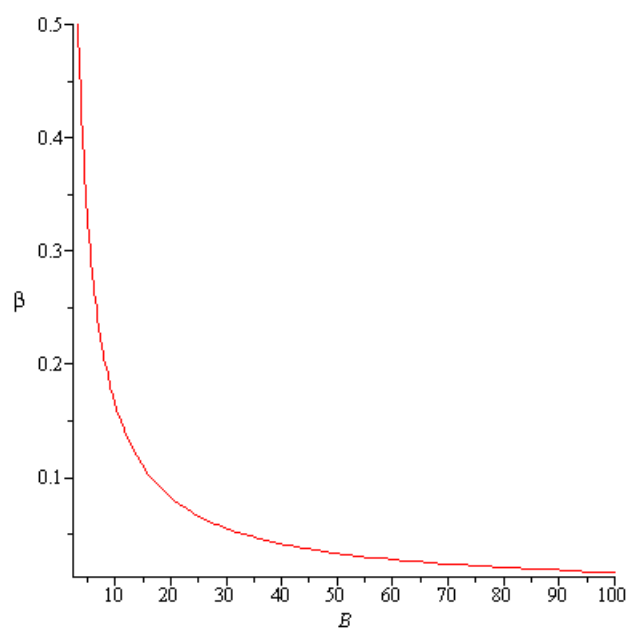

Gambar 3. Grafik level set $R_{0}$ terhadap parameter $\beta$ dan $\mathrm{B}$

\subsection{Pembahasan}

Dinamika sistem persamaan (1) - (5) dapat diamati melalui titik kesetimbangan solusi atau titik kritis. Dengan mengamati persamaan (1) - (5) pada kondisi stagnan atau tidak terdapat perubahan, didapatkan 2 titik kritis, yaitu titik kritis bebas rokok dan titik kritis endemik. Titik kritis bebas rokok menggambarkan tidak ada individu terpengaruh rokok sedangkan titik kritis endemik memperlihatkan bahwa terdapat individu yang terpengaruh rokok dalam populasi, artinya perilaku merokok akan endemik.

Eksistensi titik kritis bebas rokok tercapai jika $S>0$ dan $S_{T}>0$ dan titik kritis endemik $\left(\mathrm{T}_{2}\right)$ tercapai jika $S^{*}>0, S_{T}{ }^{*}>0, D^{*}>0, A^{*}>0$, dan $R^{*}>0$. Kestabilan model di titik kritis bebas rokok $\left(\mathrm{T}_{1}\right)$ akan stabil saat $R_{0}<1$ dan titik kritis endemik $\left(\mathrm{T}_{2}\right)$ akan stabil saat $R_{0}>1$.

Simulasi model untuk nilai-nilai parameter pada tabel 1 memberikan bilangan reproduksi dasar $\left(R_{0}\right)$ sebesar 305,3185523 . Karena nilai $\left(R_{0}\right)$ lebih besar dari satu maka perilaku 
merokok tidak akan hilang dari populasi serta menyebabkan endemik dalam populasi, seperti diperlihatkan pada Gambar 2. Nilai $\left(R_{0}\right)$ lebih besar dari satu berarti setiap perokok dapat menularkan perilaku merokoknya kepada lebih dari satu perokok baru sehingga pada akhirnya penyebaran perilaku merokok yang meluas.

Gambar 2. menunjukkan subpopulasi berpotensi menjadi perokok mengalami penurunan. Sedangkan subpopulasi yang hanya coba-coba dan subpopulasi perokok mengalami kenaikan yang cukup signifikan. Hal ini disebabkan kerena besarnya laju infeksi rokok yang terjadi dalam populasi. Interaksi antara subpopulasi berpotensi menjadi perokok dengan subpopulasi perokok akan mempengaruhi orang untuk merokok.

Gambar 2. juga menunjukkan subpopulasi yang berpotensi menjadi perokok dan subpopulasi yang diberikan treatment mengalami penurunan. Sedangkan subpopulasi yang hanya coba-coba merokok, subpopulasi perokok dan subpopulasi yang sembuh dari pengaruh rokok mengalami peningkatan. Setiap subpopulasi terus mengalami perubahan jumlah hingga mencapai titik setimbang endemik. Endemik berarti perilaku merokok yang terjadi dengan laju konstan namun cukup tinggi pada suatu populasi. Hal ini menunjukkan perilaku merokok tidak akan pernah menghilang dalam populasi atau dengan kata lain selalu terjadi endemik penyebaran perilaku merokok. Subpupulasi perokok akan selalu eksis dalam populasi pengamatan.

Gambar 3. menunjukkan daerah kestabilan sistem terhadap perubahan nilai $\beta$ dan B. Sistem akan stabil bila nilai parameter $\beta$ dan B berada di bawah kurva tersebut. Sedangkan sistem akan tidak stabil bila nilai parameter $\beta$ dan B berada di atas kurva. Kurva tersebut juga memperlihatkan bahwa semakin besar tingkat perekrutan individu rentan (B), maka tingkat penginfeksian rokok $(\beta)$ harus semakin kecil.

\section{KESIMPULAN}

1. Model penyebaran perilaku merokok berdasarkan faktor biologis dan faktor lingkungan sosial adalah:

$$
\begin{aligned}
& \frac{d S_{T}}{d t}=\alpha_{1} S-\left(\alpha_{2}+\mu\right) S_{T} \\
& \frac{d S}{d t}=\mathrm{B}-\left(\beta A+\mu+\alpha_{1}\right) S+\sigma R+\alpha_{2} S_{T} \\
& \frac{d D}{d t}=\beta S A+\tau A-\left(\rho+\gamma_{1}+\mu\right) D \\
& \frac{d A}{d t}=\rho D-\left(\mu+v+\gamma_{2}+\tau\right) A \\
& \quad \frac{d R}{d t}=\gamma_{1} D+\gamma_{2} A-(\sigma+\mu) R
\end{aligned}
$$


2. Dari SPD di atas didapatkan dua titik kritis yaitu titik kritis bebas rokok yang diekspresikan sebagai $T_{1}=\left(\frac{\alpha_{1} B}{\mu\left(\mu+\alpha_{1}+\alpha_{2}\right)}, \frac{B\left(\alpha_{2}+\mu\right)}{\mu\left(\mu+\alpha_{1}+\alpha_{2}\right)}, 0,0,0\right)$ dan titik kritis endemik yang diekspresikan sebagai $T_{2}=\left(S_{T}{ }^{*}, S^{*}, D^{*}, A^{*}, R^{*}\right)$ dimana:

$$
\begin{aligned}
& S_{T}{ }^{*}=\frac{\alpha_{1}\left(\rho \mu+\rho v+\rho \gamma_{2}+\gamma_{1} \mu+\gamma_{1} v+\gamma_{1} \tau+\gamma_{1} \gamma_{2}+\mu^{2}+\mu v+\mu \gamma_{2}+\mu \tau\right)}{\beta \rho\left(\alpha_{2}+\mu\right)} \\
& S^{*}=\frac{\left(\rho \mu+\rho v+\rho \gamma_{2}+\gamma_{1} \mu+\gamma_{1} v+\gamma_{1} \tau+\gamma_{1} \gamma_{2}+\mu^{2}+\mu v+\mu \gamma_{2}+\mu \tau\right)}{\beta \rho} \\
& D^{*}=\frac{\left(\mu+v+\gamma_{2}+\tau\right)\left(B \beta \rho\left(\alpha_{2}+\mu\right)-\mu\left(\alpha_{2}+\mu+\alpha_{1}\right)\left(\rho \mu+\rho v+\rho \gamma_{2}+\gamma_{1} \mu+\gamma_{1} v+\gamma_{1} \tau+\gamma_{1} \gamma_{2}+\mu^{2}+\mu v+\mu \gamma_{2}+\mu \tau\right)\right)(\sigma+\mu)}{\beta \rho\left(\left(\sigma\left(\rho \mu+\rho v+\mu^{2}+\mu v+\mu \gamma_{2}+\mu \tau\right)+\mu\left(\rho \mu+\rho v+\rho \gamma_{2}+\gamma_{1} \mu+\gamma_{1} v+\gamma_{1} \tau+\gamma_{1} \gamma_{2}+\mu^{2}+\mu v+\mu \gamma_{2}+\mu \tau\right)\right)\right)} \\
& A^{*}=\frac{\left(B \beta \rho\left(\alpha_{2}+\mu\right)-\mu\left(\alpha_{2}+\mu+\alpha_{1}\right)\left(\rho \mu+\rho v+\rho \gamma_{2}+\gamma_{1} \mu+\gamma_{1} v+\gamma_{1} \tau+\gamma_{1} \gamma_{2}+\mu^{2}+\mu v+\mu \gamma_{2}+\mu \tau\right)\right)(\sigma+\mu)}{\beta\left(\sigma\left(\rho \mu+\rho v+\mu^{2}+\mu v+\mu \gamma_{2}+\mu \tau\right)+\mu\left(\rho \mu+\rho v+\rho \gamma_{2}+\gamma_{1} \mu+\gamma_{1} v+\gamma_{1} \tau+\gamma_{1} \gamma_{2}+\mu^{2}+\mu v+\mu \gamma_{2}+\mu \tau\right)\right)} \\
& R^{*}=\frac{\left(\rho \gamma_{2}+\gamma_{1}\left(\mu+v+\gamma_{2}+\tau\right)\right)\left(B \beta \rho\left(\alpha_{2}+\mu\right)-\mu\left(\alpha_{2}+\mu+\alpha_{1}\right)\left(\rho \mu+\rho v+\rho \gamma_{2}+\gamma_{1} \mu+\gamma_{1} v+\gamma_{1} \tau+\gamma_{1} \gamma_{2}+\mu^{2}+\mu v+\mu \gamma_{2}+\mu \tau\right)\right)}{\beta \rho\left(\left(\sigma\left(\rho \mu+\rho v+\mu^{2}+\mu v+\mu \gamma_{2}+\mu \tau\right)+\mu\left(\rho \mu+\rho v+\rho \gamma_{2}+\gamma_{1} \mu+\gamma_{1} v+\gamma_{1} \tau+\gamma_{1} \gamma_{2}+\mu^{2}+\mu v+\mu \gamma_{2}+\mu \tau\right)\right)\right)}
\end{aligned}
$$

3. Dari analisis yang dilakukan di setiap titik kritis, didapatkan syarat kestabilan pada masing-masing titik kritis, yaitu $T_{1}$ stabil jika $R_{0}<1$, dan endemik stabil jika $R_{0}>1$, dengan $R_{0}$ adalah Bilangan Reproduksi Dasar yang diekspresikan sebagai:

$R_{0}=\frac{\rho \beta B\left(\alpha_{2}+\mu\right)}{\mu\left(\mu+\alpha_{1}+\alpha_{2}\right)\left(\rho \mu+\rho v+\rho \gamma_{2}+\gamma_{1} \mu+\gamma_{1} v+\gamma_{1} \gamma_{2}+\gamma_{1} \tau+\mu^{2}+\mu v+\mu \gamma_{2}+\mu \tau\right)}$.

4. Nilai $R_{0}<1$ maka populasi akan bebas dari rokok. Sedangkan nilai $R_{0}>1$ maka perilaku merokok tidak akan hilang dari populasi serta menyebabkan endemik dalam populasi yang berarti setiap perokok dapat menularkan perilaku merokoknya kepada lebih dari satu perokok baru sehingga pada akhirnya penyebaran perilaku merokok yang meluas.

\section{DAFTAR PUSTAKA}

[1]. Davidson, G.C dan Neale, J.M.,1990, Abnormal Psychology, Willey \& Sons, New York.

[2]. Kaplan, R.M., Sallis, J.F dan Patterson, T.L., 1993, Health and Human Behavior, Mc Graw-Hill Book Co, New York.

[3]. Maziyyatul, F., 2011, Gambaran Faktor- Faktor Yang Mempengaruhi Perilaku Merokok Pada Mahasiswa Laki-Laki, Universitas Indonesia. Jakarta.

[4]. Renny, A. N. P., 2011, Hubungan antara dimensi kepribadian Big Five dengan perilaku merokok pada remaja akhir, Skripsi. Fakultas Psikologi Universitas Islam Negeri Syarif Hidayatullah, Jakarta.

[5]. Republika., 1998, Lebih Tiga Juta Meninggal karena Tembakau dalam Setahun. Harian Republika. 30 Oktober 1998.

[6]. Satiti, A., 2009., Strategi Rahasia Berhenti Merokok, Datamedia, Jakarta.

[7]. Smet, B., 1994, Psikologi Kesehatan, PT Gramedia Widiasarana Indonesia, Jakarta. 